\title{
Learning Environment Through Dance Movement
}

\author{
Dwiyana Habsary ${ }^{1}$, Indra Bulan ${ }^{2}$, Afizal Yudha $S .^{3}$ \\ \{habsarydwiyana@gmail.com ${ }^{1}$, Indra89bulan@gmail.com ${ }^{2}$, afrizalpiano@gmail.com ${ }^{3}$ \}
}

Dance Education, Lampung University, Indonesia ${ }^{1,2,3}$

\begin{abstract}
This article discusses dance movements that describe the environment in the Lampung area. The environment that is depicted through dance movements also contains cultural values that are transmitted to the next generation. This study uses phenomenological theory and meaning in revealing the environmental image contained in a dance movement. Data obtained by means of observation, interviews, and documentation. Some of the movements that describe the environment in Lampung traditional dance are kenui melayang, samber melayang, ngiyaw bias, and seluang mudik. The environment depicted shows that the relationship between the community and the environment is very close and can be used as an effort to preserve the environment.
\end{abstract}

Keywords: Dance, Meaning, Movement.

\section{Introduction}

Learning is a human activity that never stops. By learning, humans who initially did not know became aware. Learning is a process that makes humans understand something. However, not all subjects can be clearly captured by students. One of them is the field of art, especially dance. There needs to be special assistance for students to understand the dance material being studied. Dance material not only includes cognitive abilities, but also includes psychomotor and affective abilities or attitudes. These three domains will be touched by educators if they have the ability to understand dance not only its movements, but also to understand dance contextually.

A comprehensive explanation of dance is very, very necessary to understand a dance well. This will be useful for students to express dance movements, and learn the area of origin of a dance. For that an educator needs a way to understand and convey this understanding to students. This article will discuss dance originating from one of the regions, namely Lampung. However, this article does not discuss one complete dance form, but rather discusses several movements taken from several dances in the Lampung area.

Dance movements that will be discussed in this article are kenuy melayang, seluang mudik, injak lado, ngiyaw bias. These movements are movements found in the Lampung traditional dance. This movement is also a movement found in the female dance (in Lampung language it is called muli) in the Lampung area. This article attempts to describe how the Lampung people interact with their environment.

\section{Discussion}

A dance choreography is a series of pictures, or vivid paintings [1]. Each of these images or movements has its own contribution to a choreography. However, a dance movement can 
stand alone and tell something or a condition. Of course, this condition cannot be separated from the origin of a motion. The original purpose here is, the area that has the movement. A dance movement can describe a situation, behavior, condition of a person's soul, even the environment of an area. Likewise, only with the movements contained in the dances in the Lampung area.

The people of Lampung have their own uniqueness, especially regarding their customs. Traditional Lampung consists of the Pepadun and Saibatin customs. Each custom has its own language style. This language is also used in naming dance movements. The dance movement originating from the Lampung area, besides using the Lampung language, also describes the condition of the Lampung area. Especially the condition of the community and its environment $[2]$.

The floating kenuy motion according to the meaning of the word itself consists of two words, namely kenui and melayang. Kenui means eagle. Hover means hovering, so that when combined, kenui melayang means a hovering hawk. Flying means to spread the wings in the sky. Things that can be taken are explained in this motion, how to visualize the dance movement depicting a hovering eagle. Representation of hovering motion by extending both arms to the side.

Another movement is seluang mudik, consisting of two words, namely seluang, which is a type of fish consumed by the people of Lampung. Then the word mudik, which means return. This movement is described by the movement of the fingers that are moved to the right, left, right, then back to the center. The word mudik can also come from the word kemudik (Lampung) which means small. Seluang fish have a small size and live in groups, are freshwater fish that are widely found in rivers in the Lampung area.

Next is injak lado, consisting of two words, namely stepping which means stepping on, then lado which means pepper. This movement is indicated by alternating leg movements. The sole of the foot consists of the part that is close to the fingers, then the part that is close to the heel. These two parts alternate stepping and then simultaneously. Describes the process of stepping on a pepper.

The last motion that will be discussed in this article is ngiyaw bias, consisting of two words, namely ngiyaw which means washing, then bias which means rice. This motion is described by hand movements and finger movements with a cleaning attitude. The cleaning attitude is the gesture of the fingers touching each other. These fingers are the middle finger, ring finger, and thumb. This movement describes the process when washing rice.

The explanation of these movements can give a real picture that the Lampung people are very, very popular with the eagle. The eagle is also sometimes analogous to the eagle. The eagle is a symbol of courage, majesty. The symbol of the Garuda bird will be encountered very often during traditional ceremonies. The eagle is also a picture of a vehicle when the traditional procession is in progress. Another illustration that can be learned from this movement is how the people of Lampung like things that are great and strong. The eagle is one of the birds that can survive for decades. Another explanation is closely related to the eagle's own habitat. The eagle needs a comfortable place to live in order to survive. A comfortable place for predatory birds like this is the forest that still provides food for bird consumption. The forest is also a safe place to survive from fellow predators themselves, as well as from human touch.

Next is the movement for seluang mudik which is a motion used to change levels. This gesture also shows that the people of Lampung are very familiar with creatures that have freshwater habitats. This fish is very often found in restaurants in Lampung that serve pindang menus. The way of life in groups is one of the factors that makes it easier for the people of Lampung to obtain these fish in large quantities. Another picture that can be captured is, 
regarding the geographical Lampung where there are many rivers that have a lot of yield and can be used by the surrounding community.

The injak lado is an illustration that a plant that is commonly found in the Lampung area is pepper. This plant is one of the typical plants and is a product of the Lampung region. The abundance of these plants has made the Lampung region dub itself 'Tanoh Lado' which means ground pepper. Pepper soil can also be interpreted as a place that produces pepper. Lampung itself is one of the regions that exports pepper.

The next motion is ngiyaw bias. A movement that shows the behavior of the people of Lampung in preparing the main dish. Based on this movement, it shows that, the staple food of the people of Lampung is rice, produced from cooked rice. The process before cooking itself begins with washing the rice first. The image shown in motion is a hand motion that is performed in a circular manner. This is a visualization of the rice washing process.

Based on this explanation, a scheme for the relationship between the people of Lampung and their environment can be made as follows.

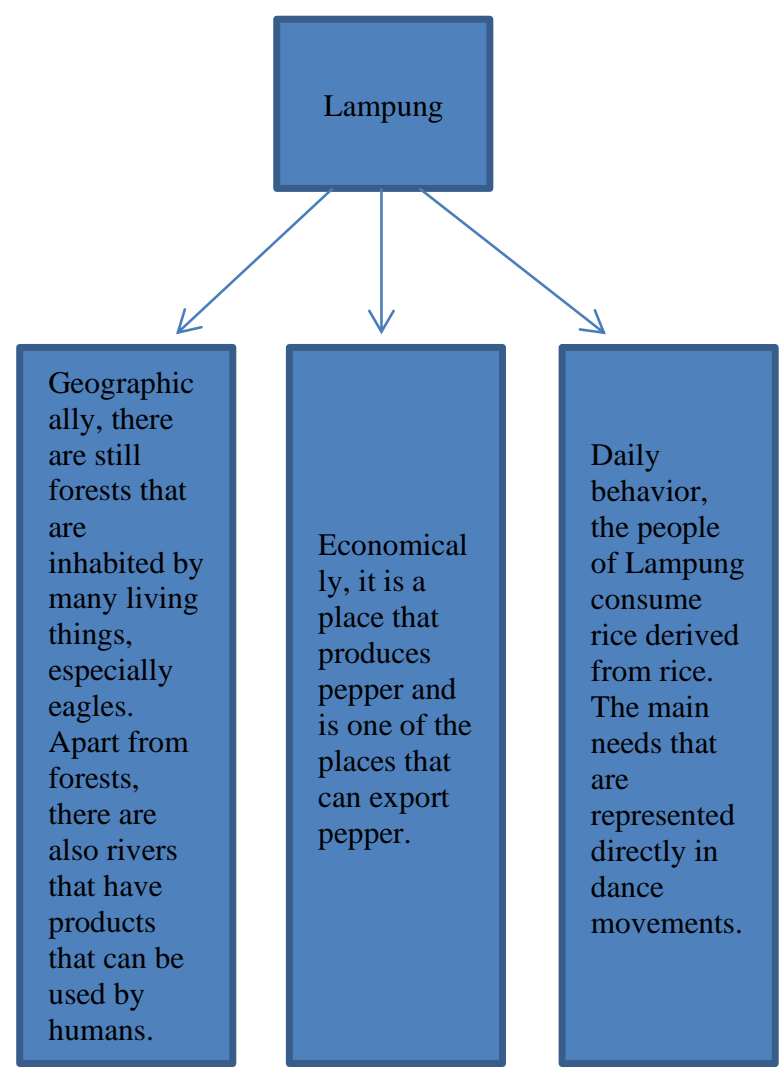

Fig. 1. Environment of Lampung in Dance Movement

Based on the Figure 1 above, it can be captured, that the learning material at school can provide broad understanding to students. This is shown from several examples of dance movements in the Lampung area. The explanation will become even wider if it is conical on a dance form. The extent of this explanation will cover the theme of the dance, the costumes used, 
the properties, the floor design, and the dance accompaniment. All of these elements can be explored in detail using the method exemplified above. The explanation of this method requires an educator who has a broad knowledge.

Acknowledgments. Lampung traditional dance movements describe the environmental conditions of the people of Lampung. Some of these conditions are the living environment that describes human interactions with the surrounding living things, namely animals, bodies and humans. The picture of interactions with animals is a description of the eagle, and plants that live in the Lampung area and become a source of livelihood as well as a characteristic of the Lampung area. This characteristic can also be seen from the symbol of the Lampung area. What can be learned is that the people of Lampung show the diversity of living things in the Lampung area. This diversity lives side by side and maintains balance.

Another material that can be used as material in learning for students is the value of respecting the environment. This value is manifested by elevating the environment through aesthetic experiences. This aesthetic experience is the experience of movement contained in a dance. This aesthetic experience can cover all aspects that can be achieved in a lesson. The first is the knowledge aspect, students can find out what things are in their environment. Psychomotor aspects, students can imitate motion that describes the conditions of their environment. Affective aspects, students can be trained to respect their environment, and foster an attitude of belonging so that they can foster a sense of responsibility to protect the environment.

\section{References}

[1] Meri, La. Dance Composition the Basic Elements. Massachusetts: Jacob's Pillow Dance Festival. 1965.

[2] Hadikusuma, Hilman, et al. Adat Istiadat Lampung. Lampung: CV. Arian Jaya. 1996. 